\title{
Accessibility of Enterobacterial Common Antigen to Antibodies in Encapsulated and Non-capsulated S and R Forms of Escherichia coli
}

\author{
By G. ACKER, ${ }^{1}$ G. SCHMIDT ${ }^{2}$ AND H. MAYER ${ }^{2 *}$ \\ ${ }^{1}$ Institut für Klinische Mikrobiologie und Infektionshygiene der Universität Erlangen- \\ Nürnberg, D-8520 Erlangen, West Germany \\ ${ }^{2}$ Max-Planck-Institut für Immunbiologie, D-7800 Freiburg, West Germany
}

(Received 7 August 1981; revised 4 November 1981)

\begin{abstract}
Antiserum specific for the enterobacterial 'common antigen' (ECA) was obtained by absorbing a rabbit ECA antiserum with an ECA-negative mutant. Accessibility of ECA to antibodies in encapsulated and non-capsulated S and R forms derived from Escherichia coli 08:K27 was studied using the indirect immunoferritin technique (whole-mount electron microscopy). The number of ferritin particles on the bacterial surface decreased in the order, non-capsulated $R>$ encapsulated $R>$ non-capsulated $S>$ encapsulated $S$ form, indicating that both the $\mathrm{O}$ and $\mathrm{K}$ antigens partly cover ECA on the surface of the outer membrane. Whole-mount and thin-section electron microscopy showed that ferritin was evenly distributed on the surface of $\mathrm{R}$ mutants, whereas it formed clusters on the $\mathrm{S}$ forms.
\end{abstract}

\section{INTRODUCTION}

The enterobacterial 'common antigen' (ECA), discovered in 1962 by Kunin (Kunin et al., 1962; Mayer \& Schmidt, 1979), is localized in the outer membrane of the enterobacterial cell envelope. This had first been indicated by the phagocytosis-promoting and bactericidal activities of ECA antibodies (Domingue \& Neter, 1966a,b).

Recently, ECA has been directly demonstrated in the outer membrane of $\mathbf{R}$ mutants of Escherichia coli using monospecific ECA antiserum and fluorescein- or ferritin-conjugated anti-rabbit IgG antibodies (Rinno et al., 1980). The specificity of the reaction was indicated by the failure of this antiserum to label an isogenic ECA-deficient $r f e$ mutant (Schmidt et al., 1976). These studies were performed with non-capsulated R mutants of $E$. coli O8.

The accessibility of ECA in enterobacterial $\mathrm{S}$ forms has so far been studied only with a fluorescent $E$. coli $\mathrm{O} 14$ antiserum containing both anti-O and anti-ECA antibodies (Aoki $e t$ al., 1966) and by the indirect immunoferritin technique with a special strain of Yersinia enterocolitica (Acker et al., 1981) which showed a marked dependence of O-chain length on growth temperature (Acker et al., 1980). In this study, we have compared the ferritin labelling of ECA in mutants derived from a strain of $E$. coli $08: \mathrm{K} 27$ and having defects in the synthesis of either the $\mathrm{O}$ chain or the $\mathrm{K}$ antigen or both, in order to investigate how the $\mathrm{O}$ and $\mathrm{K}$ polysaccharides interfere with the accessibility of ECA to antibodies.

\section{METHODS}

Bacterial strains and culture conditions. The strains used and their descriptions are given in Table 1 . The $\mathrm{R}$ mutants have the complete lipopolysaccharide (LPS) core of type R1 which is characteristic of $E$. coli D280 (Schmidt et al., 1970). Strain F782 is a his ${ }^{+}$hybrid from a cross of Hfr639 $\times$F470. The donor Hfr639 is an encapsulated $\mathrm{R}$ form $\left(\mathrm{O} 8^{-}: \mathrm{K} 27^{+}, r f b\right)$. The $h i s^{+}$hybrid $\mathrm{F} 782$ has acquired the donor genes coding for the $\mathrm{K} 27$ antigen which are closely linked to the his operon (Schmidt et al.. 1977). 
Table 1. Strains and mutants derived from the wild-type E. coli E56b

\begin{tabular}{|c|c|}
\hline Strain & Serotype \\
\hline D280 & $\mathrm{O} 8: \mathrm{K} 27: \mathrm{H}^{-}$ \\
\hline F492 & $\mathrm{O} 8: \mathrm{K}^{2} 27^{-}: \mathrm{H}^{-}$ \\
\hline$F 470$ & $\mathrm{R}: \mathrm{K} 27^{-}: \mathrm{H}^{-}$ \\
\hline F782 & $\mathrm{R}: \mathrm{K} 27: \mathrm{H}^{-}$ \\
\hline$F 1283$ & $\mathrm{R}: \mathrm{K} 27^{-}: \mathrm{H}^{-}$ \\
\hline
\end{tabular}

Description

Encapsulated $\mathrm{S}$ form, derived from E. coli $\mathrm{E} 56 \mathrm{~b}$

Non-capsulated $\mathbf{S}$ form derived from D280

Non-capsulated $\mathrm{R}$ form derived from F492

Encapsulated $\mathbf{R}$ form derived from D280

Non-capsulated $\mathbf{R}$ form derived from D280, ECA-negative $r f e$ mutant
ECA

$+$

$+\quad$ Schmidt et al. (1970)

$+\quad$ Whang et al. (1972)

$+\quad$ Whang et al. (1972)

- $\quad$ Kiss et al. (1978)

Rough strains F470 (ECA-immunogenic $r f b$ mutant) and F1283 (ECA-negative $r f e$ mutant) were used, as in a previous study (Acker et al., 1981), for the preparation of ECA-specific antiserum (see below) and as positive and negative controls for the immunoferritin technique.

For electron microscopy investigations, subcultures of these strains were used. They were grown in Tryptic soy broth (TSB, Difco) at $37^{\circ} \mathrm{C}$ and harvested in the exponential phase of growth $\left(A_{546} 0 \cdot 15-0 \cdot 17\right)$.

$K 27$ antiserum. Rabbit OK antiserum was obtained as described previously (Whang et al., 1972) after repeated injections of formalin-treated cells of $E$. coli $\mathrm{D} 280$. The $\mathrm{O} 8: \mathrm{K} 27$ antiserum was thoroughly absorbed with the $\mathrm{K}^{-}$ mutant F492 to produce the anti-K27 serum.

ECA antiserum. ECA-specific antiserum was obtained as described previously (Acker et al., 1981) by immunizing rabbits with the ECA-immunogenic strain F470 and absorbing the resulting sera at a dilution of $1: 5$ with the ECA-negative strain F1283. The passive haemagglutination test (Neter, 1956; Männel \& Mayer, 1978) showed that agglutinins against alkali-treated LPS of $E$. coli F1283 had been eliminated from the absorbed antisera, whereas the titre (1280) against ECA of Salmonella montevideo SH94 remained essentially unchanged. The specificity of the absorbed ECA antiserum was tested by the indirect immunoferritin technique (see below); cells of the ECA-immunogenic strain F470 became heavily labelled (Fig. $3 a$ ), whereas most cells of the ECA-negative mutant F 1283 were not labelled at all and only few cells showed a weak, probably non-specific, labelling ( $<20$ ferritin particles per cell). For some experiments the ECA antiserum was fractionated on an Ultrogel AcA34 (LKB) column $(12.5 \times 100 \mathrm{~cm})$ into the IgM and IgG fractions; each fraction was pooled and concentrated in collodion bags (Sartorius, Göttingen, F.R.G.) to the original volume of the absorbed ECA antiserum ( $1: 5$ dilution).

Indirect immunoferritin technique. All labelling experiments were done using the indirect immunoferritin technique as described previously (Acker et al., 1981). Two volumes of cell suspension in TSB medium (standardized to an $A_{546}$ of 0.15 ) were mixed with one volume of the absorbed ECA antiserum (heated 30 min at $56{ }^{\circ} \mathrm{C}$ ) or with the isolated $\operatorname{IgM}$ or IgG fractions and incubated for $30 \mathrm{~min}$ at $10^{\circ} \mathrm{C}$. Subsequently, the cells were washed twice $\left(15 \mathrm{~min}\right.$ at $10000 \mathrm{~g}$ ), resuspended in $2 \mathrm{ml}$ of the same medium and incubated $\left(60 \mathrm{~min}\right.$ at $\left.0^{\circ} \mathrm{C}\right)$ with ferritin-conjugated goat anti-rabbit IgG (heavy and light chains) purchased from Cappel Laboratories, Cochranville, Pa., U.S.A. Unbound antiserum components were removed by two washes in cold TSB (5000 $g$ at $4^{\circ} \mathrm{C}$ ). For controls, cells were incubated with serum taken from rabbits before immunization instead of with ECA antiserum.

The pellets were examined by whole-mount or thin-section electron microscopy. In some experiments, the labelled pellets of the encapsulated strains D280 and F782 were resuspended in $3 \mathrm{ml}$ cold TSB medium and anti-K 27 serum was added $(0.75 \mathrm{ml}$ to each sample) to preserve the capsule (Bayer \& Thurow, 1977; Acker et al., 1981). The samples were incubated for $30 \mathrm{~min}$ at $0^{\circ} \mathrm{C}$, washed twice in cold TSB medium ( $15 \mathrm{~min}$ at $5000 \mathrm{~g}$ ), and then examined by the thin-section technique.

Electron microscopy. (a) Thin-section technique. The cells were fixed with glutaraldehyde- $\mathrm{OsO}_{4}$ and embedded in Epon 812 as described previously (Traub et al., 1976). Thin-sections were cut with an LKB ultramicrotome (Ultratome III) and contrasted with $2 \%(\mathrm{w} / \mathrm{v})$ aqueous uranyl acetate and lead citrate (Reynolds, 1963). (b) Whole-mount technique. Pellets of the treated samples were resuspended in distilled water and adsorbed to carbon films according to the procedure described by Valentine et al. (1968). They were then observed in the electron microscope as whole mounts. All preparations were examined with a JEOL JEM-100B electron microscope.

\section{RESULTS}

\section{Thin-section electron microscopy}

In a first series of experiments cells were examined by thin-section electron microscopy. The outermost layer of the cells of all strains examined was the outer membrane (Fig. $1 a$ ). 

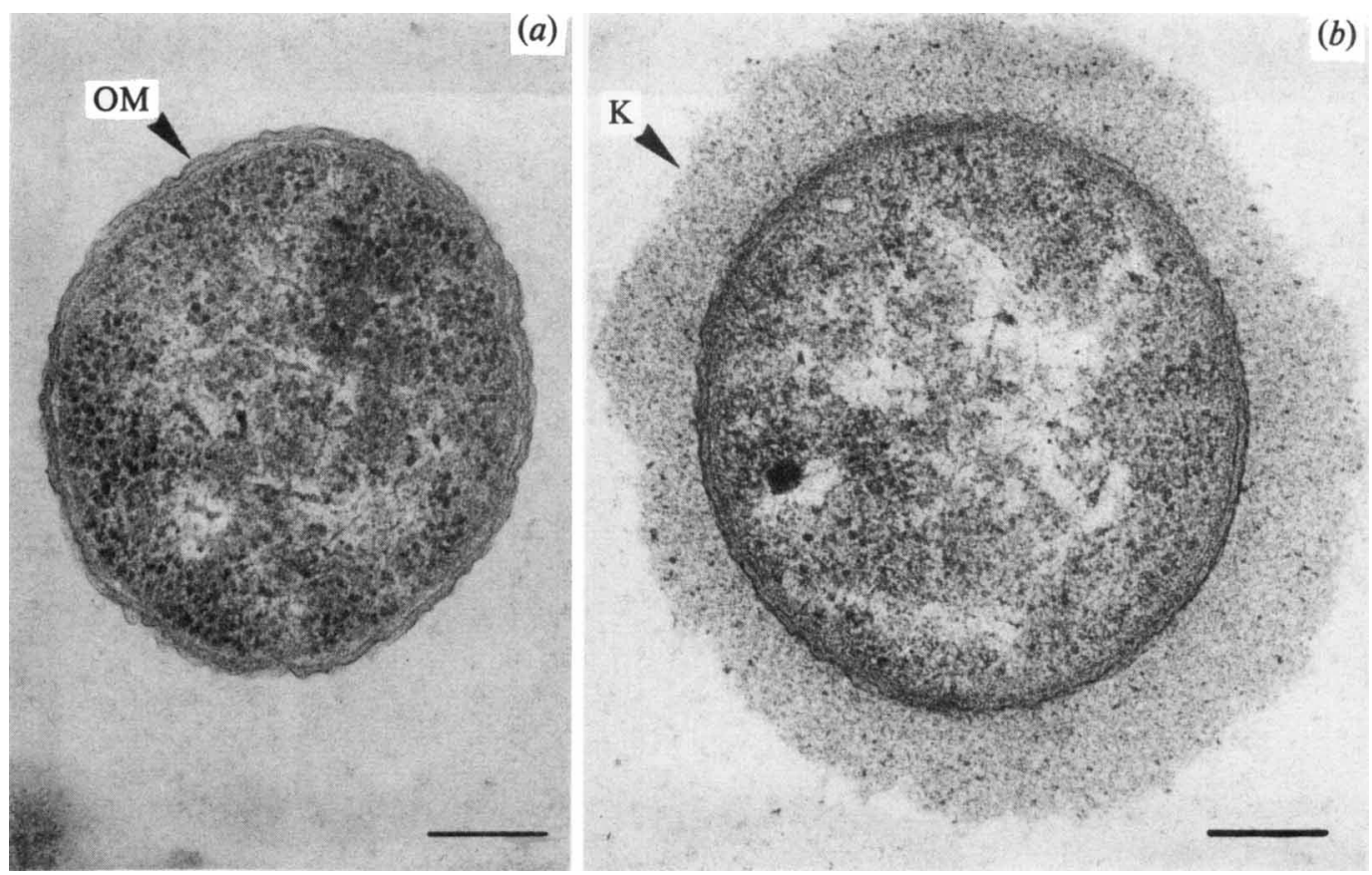

Fig. 1. Thin-section micrographs of cells of the encapsulated wild-type strain D280 (O8:K27): (a) untreated; $(b)$ treated with anti-capsule (K27) serum before preparation of thin section. Note the thick capsule $(\mathrm{K})$ that appears on the cell surface after treatment with anti-capsule serum. OM denotes the outer membrane. The bar markers represent $0.2 \mu \mathrm{m}$.

When cells were incubated with the homologous anti-capsule (K27) serum prior to their preparation for electron microscopy, a thick capsule was observed on cells of the encapsulated wild-type strain D280 (Fig. 1 b) and on cells of the encapsulated R mutant F782 (not shown). As expected, cells of the non-capsulated S and R forms F492 and F470 treated in the same way did not show a capsule on their surface (not shown).

In order to study the accessibility of ECA to antibodies in the encapsulated and non-capsulated strains, the cells were incubated with rabbit ECA antiserum and subsequently with ferritin-conjugated goat anti-rabbit antibodies to identify the attached ECA antibodies on the cells. Washed cells of the encapsulated strains were further incubated with anti-capsule serum to visualize the bacterial capsule. Thin-section micrographs showed that cells of strains F470, F782, F492 and D280 were all labelled with ferritin, but the degree of labelling differed from strain to strain (Fig. $2 a-d$ ). The ECA-negative strain F1283 was not labelled at all (not shown) despite the fact that it was a non-capsulated $\mathrm{R}$ form.

\section{Whole-mount electron microscopy}

With the non-capsulated R form F470 a very dense labelling was observed by the whole-mount technique (Fig. $3 a$ ). Cells of the encapsulated R form F782 were also labelled but somewhat less densely than cells of strain F470 (not shown). The non-capsulated S form F492 showed a weaker labelling, and the ferritin was found in clusters (Fig. $3 b$ ). The encapsulated S strain D280 was only weakly labelled (not shown).

Similar differential labelling was observed when the IgM fraction of ECA antiserum was used instead of the ECA antiserum. The number of ferritin particles per $\mu \mathrm{m}^{2}$ of whole-mount micrographs was found to decrease in the same order (non-capsulated $R>$ encapsulated $R>$ non-capsulated S > encapsulated S; Table 2). In experiments with the IgG fraction of ECA antiserum, ferritin labelling was denser, but the results were essentially the same (not shown). 
(a)

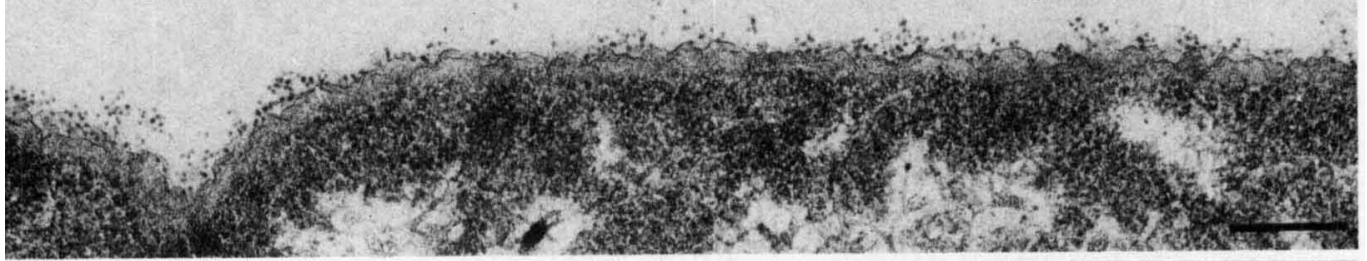

(b)

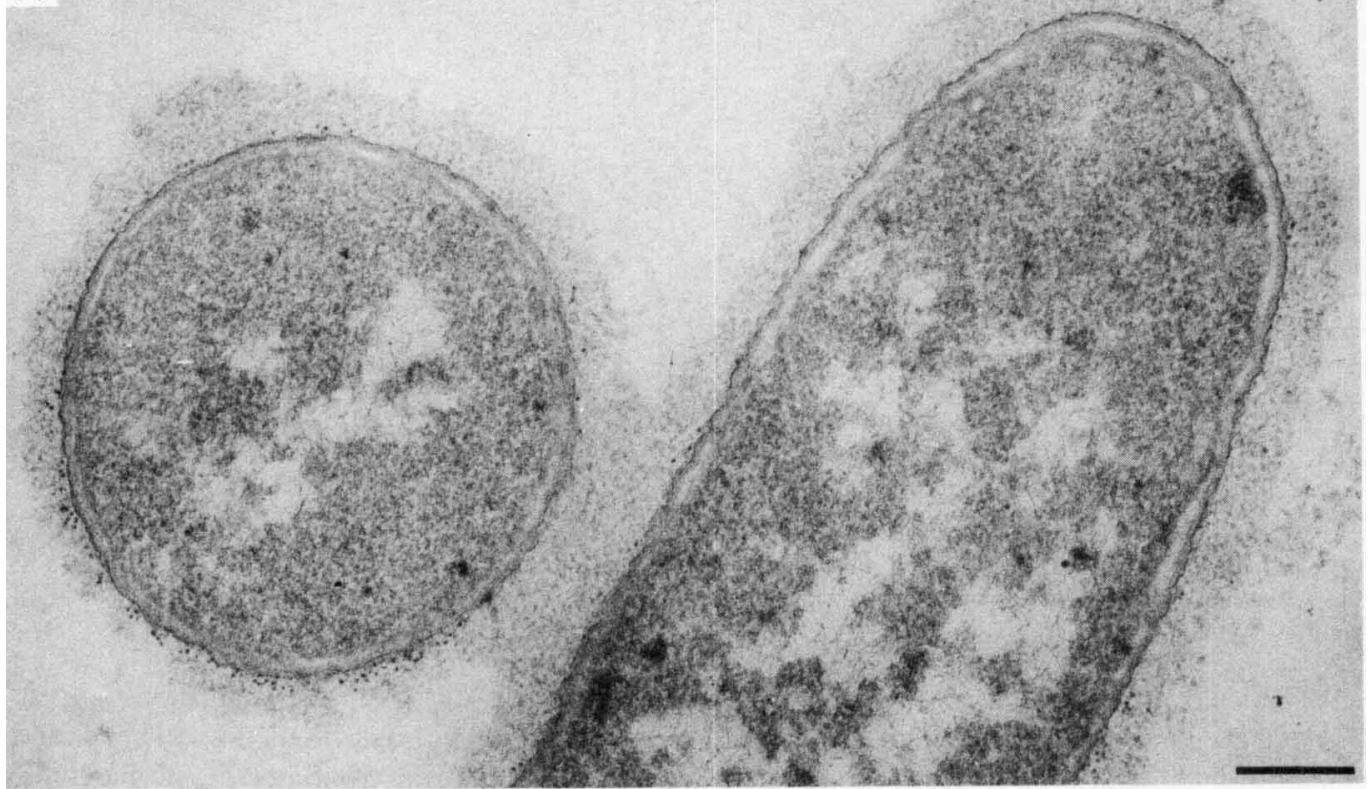

(c)

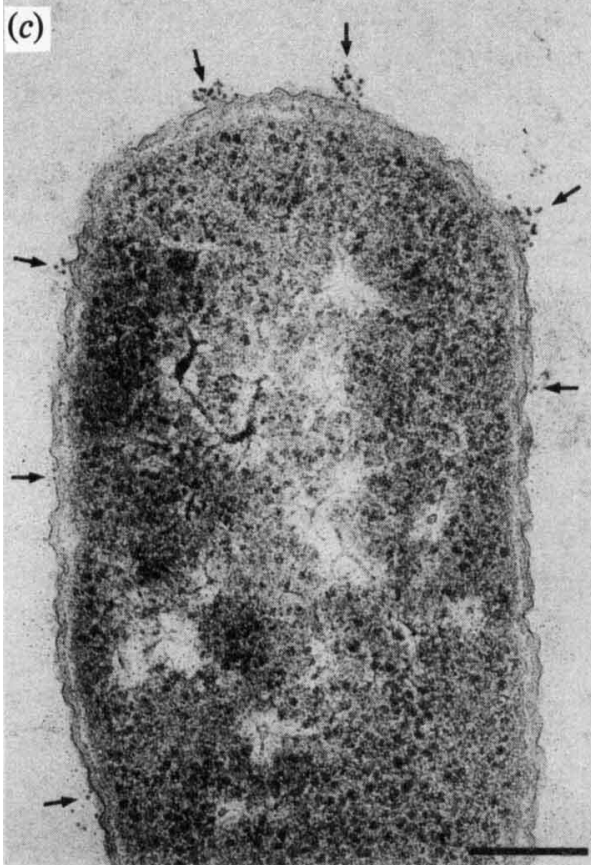

(d)

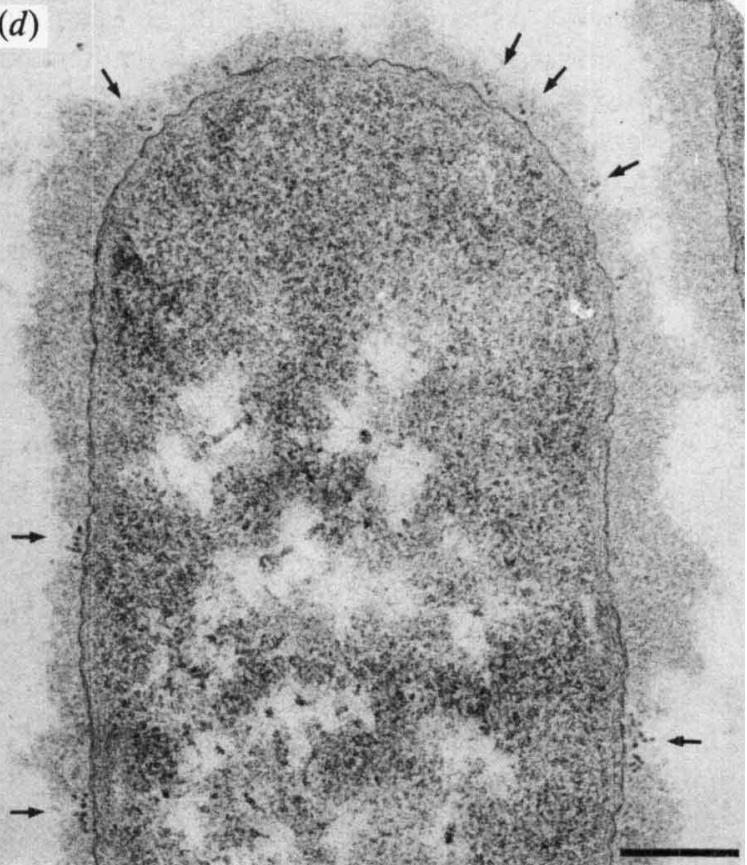

Fig. 2. Thin-section micrographs of cells after incubation with rabbit ECA antiserum and labelling with ferritin-conjugated goat anti-rabbit $\mathrm{IgG}$; in $(b)$ and $(d)$ the cells were further treated with anti-capsule serum to preserve the capsule. (a) Non-capsulated $\mathrm{R}$ form, F470 $\left(\mathrm{O8}^{-}: \mathrm{K}^{2} 7^{-}\right)$: the outer side of the 
(a)

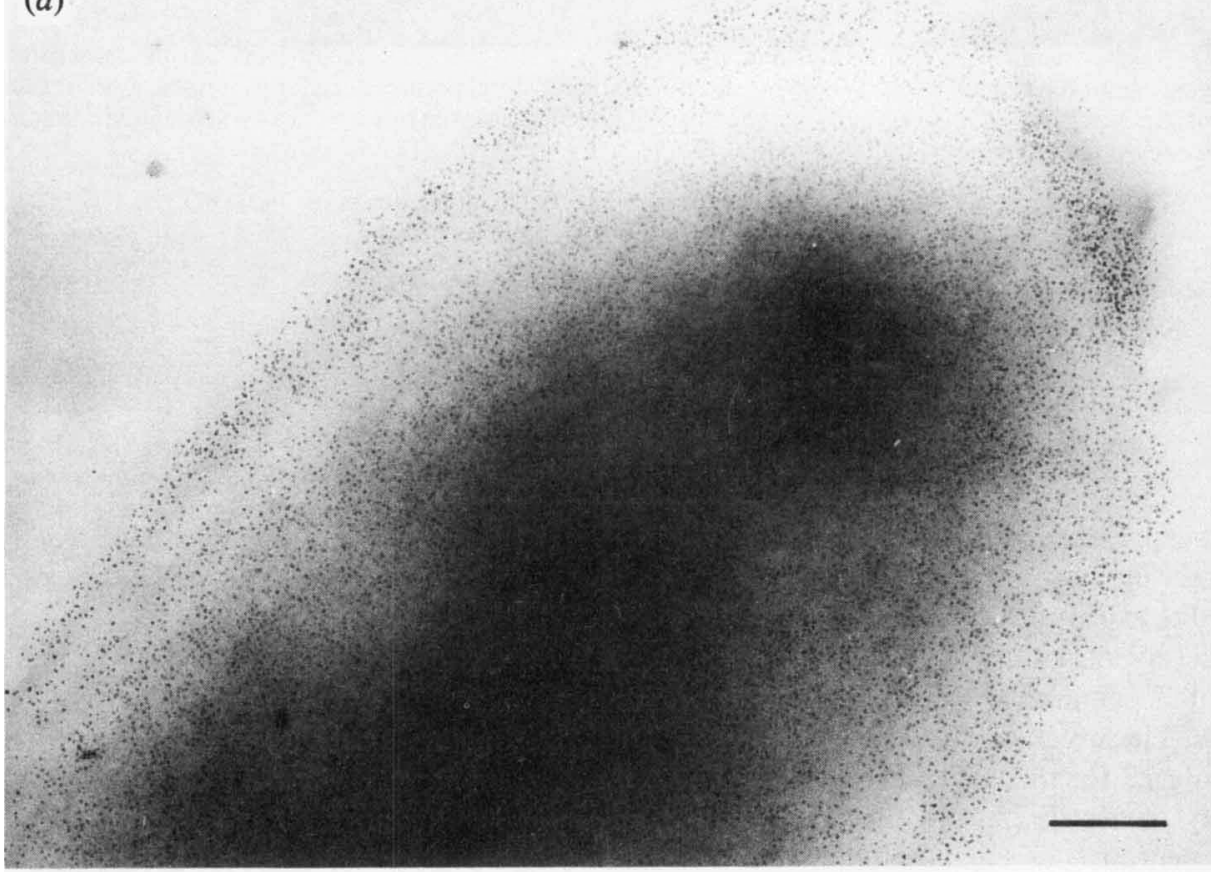

(b)

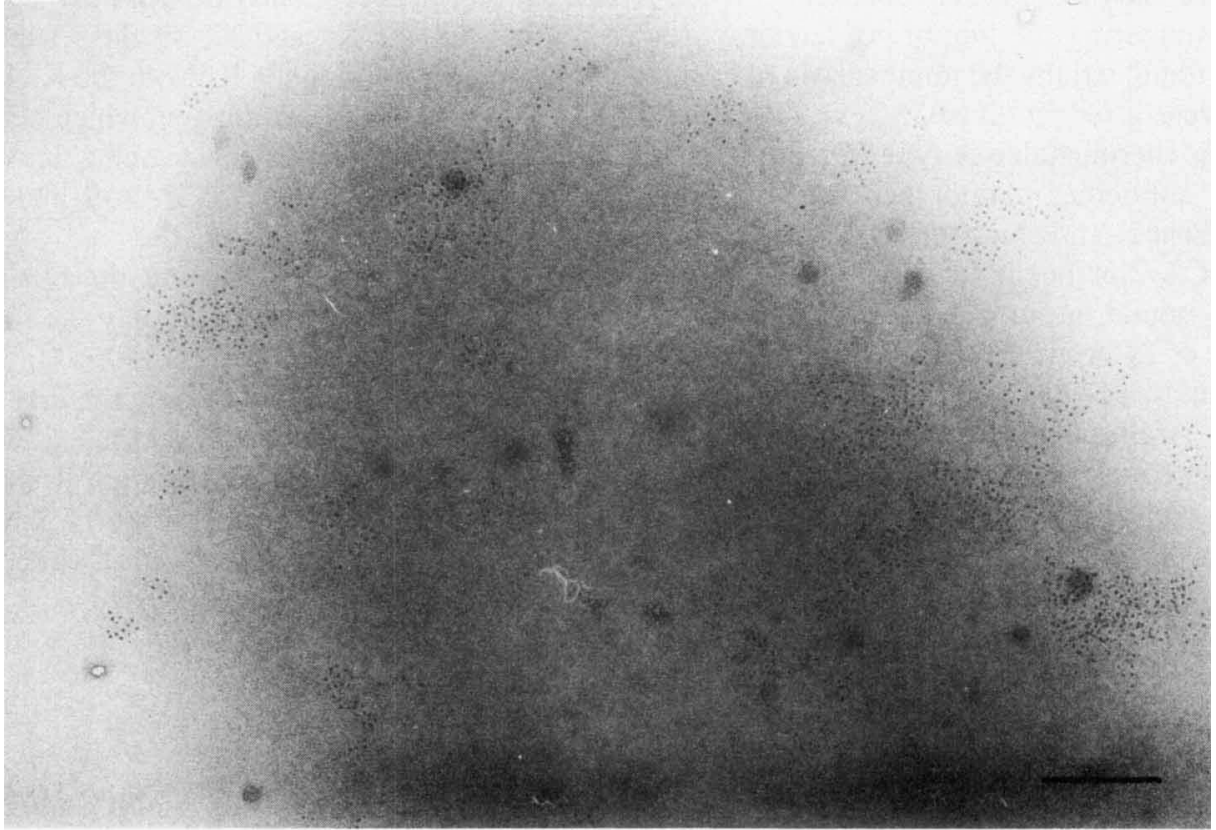

Fig. 3. Whole-mount micrographs of cells after incubation with rabbit ECA antiserum and labelling with ferritin-conjugated goat anti-rabbit IgG. (a) Non-capsulated R form, F470 $\left(\mathrm{OB}^{-}: \mathrm{K}_{2} 7^{-}\right)$: the cell shows a dense and uniform distribution of ferritin (positive control). (b) Non-capsulated S form, F492 $\left(08: \mathrm{K}_{27^{-}}\right)$: the ferritin particles are clustered. The bar markers represent $0.2 \mu \mathrm{m}$.

outer membrane shows many ferritin particles (dark dots), indicating ECA. (b) Encapsulated R form, F782 (O8- : K27): the ferritin particles indicating ECA are located beneath the capsule on the surface of the outer membrane. (c) Non-capsulated S form, F492 (O8:K27-): clusters of ferritin particles are visible (arrowed). (d) Encapsulated S form, D280 (O8:K27): ferritin particles are located on the outer membrane beneath the capsule (arrowed). The bar markers represent $0.2 \mu \mathrm{m}$. 
Table 2. Numbers of ferritin particles attached to the surface of bacteria

Cells were treated with rabbit ECA antiserum (IgM fraction) and subsequently with ferritin-conjugated goat anti-rabbit antibodies. Whole-mount micrographs were prepared and the numbers of ferritin particles per $\mu \mathrm{m}^{2}$ of micrograph were counted. The results show the mean values ( \pm standard deviation) for seven determinations.

$\begin{array}{llc}\text { Strain } & \text { Serotype } & \begin{array}{c}\text { No. of ferritin } \\ \text { particles per } \mu \mathrm{m}^{2}\end{array} \\ \text { F470 } & \text { O8 }^{-}: \mathrm{K}^{2} 27^{-} & 943( \pm 82) \\ \text { F782 } & \text { O8 }^{-}: \mathrm{K} 27 & 148( \pm 62) \\ \text { F492 } & {\text { O8 }: \mathrm{K} 27^{-}}^{-} & 66( \pm 18) \\ \text { D280 } & \text { O8:K27 } & 23( \pm 11)\end{array}$

\section{DISCUSSION}

The presence of ECA and its accessibility to antibodies could be demonstrated by the indirect immunoferritin technique in all the strains and mutants of $E$. coli $08: \mathrm{K} 27$ examined with the exception of the ECA-negative strain F1283.

The average number of ferritin particles attached to the surface of the bacteria (particles counted per $\mu \mathrm{m}^{2}$ of micrograph) was used as a quantitative measure of the accessibility of ECA. These values varied greatly, ranging from 943 for the non-capsulated $R$ strain (F470) to only 23 for the encapsulated $\mathrm{S}$ strain (Table 2), suggesting that both the $\mathrm{O}$ and $\mathrm{K}$ antigens partly cover ECA on the surface of the outer membrane. However, since only one representative of each mutant type was studied this conclusion must be taken with some reservation, especially since also only one $\mathrm{O}: \mathrm{K}$ type was studied.

The extent of the shielding effect of the $\mathrm{K}$ antigen on the accessibility of ECA can be seen by comparing the number of ferritin particles counted for the $\mathrm{K}^{+}$and $\mathrm{K}^{-}$strains (Table 2). For the $\mathrm{R}$ strains the number was reduced to $15 \%$ when comparing the $\mathrm{K}^{+}$with the $\mathrm{K}^{-}$form, whereas a reduction to $35 \%$ was obtained for the S strains. The K27 antigen, which belongs to the thermostable A type (Ørskov et al., 1977), does not apparently form such a dense net that antibodies cannot penetrate. Further studies with other strains of $E$. coli and with different $\mathrm{K}$ antigens are needed to reveal whether this is a general characteristic.

ECA can occur in two modifications, one the ubiquitous free ECA, and the other the LPS-bound immunogenic form (Kiss et al., 1978). The $8^{+}$strains contain only the former type of ECA, whereas the O8- ${ }^{-}$strains contain both forms (Mäkelä \& Mayer, 1976; Mayer \& Schmidt, 1979). The presence of two forms of ECA in the R strains and of only the first form in $S$ strains may also account for the observation that ferritin in the $S$ strains showed a clustered distribution (Figs $2 c, d$ and $3 b$ ), whereas it was evenly distributed in the $\mathrm{R}$ strains. One can assume that the lateral mobility of free ECA is higher than that of the LPS-bound form. Since R mutants of $E$. coli $\mathrm{O} 8: \mathrm{K} 27$ with incomplete R cores are available which lack the immunogenic form of ECA (Whang et al., 1972), this assumption can be tested.

The valuable technical assistance of A. Franke is gratefully acknowledged.

\section{REFERENCES}

ACKer, G., WARTEnberG, K. \& KNAPP, W. (1980). Zuckerzusammensetzung des Lipopolysaccharids und Feinstruktur der äusseren Membran (Zellwand) bei Yersinia enterocolitica. Zentralblatt für Bakteriologie, Parasitenkunde, Infektionskrankheiten und Hygiene (Abteilung I, Originale A) 247, 229-240.

ACker, G., KNapP, W., Wartenberg, K. \& MAyer, H. (1981). Localization of enterobacterial common antigen in Yersinia enterocolitica by the immunoferritin technique. Journal of Bacteriology 147, 602-611.

Aoki, S., Merkel, M. \& McCAbe, W. R. (1966). Immunofluorescent demonstration of the common enterobacterial antigen. Proceedings of the Society for Experimental Biology and Medicine 121, 230234.

Bayer, M. E. \& Thurow, H. (1977). Polysaccharide 
capsule of Escherichia coli: microscope study of its size, structure, and sites of its synthesis. Journal of Bacteriology 130, 911-936.

Domingue, G. J. \& Neter, E. (1966a). Opsonizing and bactericidal activity of antibodies against common antigen of Enterobacteriaceae. Journal of Bacteriology 91, 129-133.

Domingue, G. J. \& Neter, E. (1966 b). Inhibition by lipopolysaccharide of immune phagocytosis of latex particles modified with common antigen of enteric bacteria. Proceedings of the Society for Experimental Biology and Medicine 121, 133-137.

Kiss, P., Rinno, J., Schmidt, G. \& MAYer, H. (1978). Structural studies on the immunogenic form of the enterobacterial common antigen. European Journal of Biochemistry 88, 211-218.

Kunin, C. M., Beard, M. V. \& Halmagyi, N. E. (1962). Evidence for a common hapten associated with endotoxin fractions of Escherichia coli and other Enterobacteriaceae. Proceedings of the Society for Experimental Biology and Medicine 111, 160166.

MÄKelÄ, P. H. \& MAYER, H. (1976). Enterobacterial common antigen. Bacteriological Reviews 40, 591632.

MÄNNEL, D. \& MAYER, H. (1978). Serological and immunological properties of isolated enterobacterial common antigen. European Journal of Biochemistry 86, 371-379.

Mayer, H. \& Schmidt, G. (1979). Chemistry and biology of the enterobacterial common antigen. Current Topics in Microbiology and Immunology 85, 99-151.

Neter, E. (1956). Bacterial hemagglutination and hemolysis. Bacteriological Reviews 20, 166-188.

ØRSKOv, I., ØRSKov, F., JANN, B. \& JANN, K. (1977). Serology, chemistry and genetics of $O$ and $K$ antigens of Escherichia coli. Bacteriological Reviews 41, 667-710.

REYNOLDS, E. S. (1963). The use of lead citrate at high $\mathrm{pH}$ as an electron opaque stain in electron microscopy. Journal of Cell Biology 17, 208-212.

Rinno, J., Golecki, J. R. \& MAYer, H. (1980). Localization of enterobacterial common antigen: immunogenic and nonimmunogenic enterobacterial common antigen-containing Escherichia coli strains. Journal of Bacteriology 141, 814-821.

Schmidt, G., JANN, B. \& JANN, K. (1970). Immunochemistry of R lipopolysaccharides of Escherichia coli. European Journal of Biochemistry 16, 382392.

Schmidt, G., MAyer, H. \& Mäkelä, P. H. (1976). Presence of rfe genes in Escherichia coli: their participation in biosynthesis of $\mathrm{O}$ antigen and enterobacterial common antigen. Journal of. Bacteriology 127, 755-762.

SchmidT, G., JaNN, B., JaNN, K., ØRSKov, I. \& Ørskov, F. (1977). Genetic determinants of the synthesis of the polysaccharide capsular antigen K27(A) of Escherichia coli. Journal of General Microbiology 100, 355-361.

Traub, W. H., Acker, A. \& Kleber, I. (1976). Ultrastructure surface alterations of Serratia marcescens after exposure to polymyxin B and/or fresh human serum. Chemotherapy 22, 104-113.

Valentine, R. C., Shapiro, B. M. \& Stadtman, E. R. (1968). Regulation of glutamine synthetase. XII. Electron microscopy of the enzyme from $E$. coli. Biochemistry 7, 2143-2152.

Whang, H. Y., Mayer, H., Schmidt, G. \& Neter, E. (1972). Immunogenicity of the common enterobacterial antigen produced by smooth and rough strains. Infection and Immunity 6, 533-539. 